\title{
ANALISIS KEPATUHAN PT BANK RAKYAT INDONESIA (PERSERO) TbK PADA REVISI PSAK 60
}

\author{
Lisa Christy Longgorung $^{1}$, Ventje Ilat $^{2}$ \\ ${ }^{1}$ Pendidikan Profesi Akuntansi, Fakultas Ekonomi dan Bisnis, Universitas Sam Ratulangi, J1. Kampus Bahu, \\ Manado, 95115, Indonesia \\ ${ }^{2}$ Jurusan Akuntansi, Fakultas Ekonomi dan Bisnis, Universitas Sam Ratulangi, Jl. Kampus Bahu, Manado, \\ 95115, Indonesia \\ E-mail : lisshac@gmail.com
}

\begin{abstract}
Statement of Financial Accounting Standards (SFAS) 60 adjustment in 2014 is a standard that governs the disclosure of financial instruments. This greatly affects the standard of disclosure of details of banking information Indonesia on financial assets in the financial statements, as the industry is highly regulated, allegedly the level of compliance of the Bank Rakyat Indonesia (BRI) to implement the standard was high. Financial assets consist of available-for-sale, held to maturity, loans and receivables, and financial assets at fair value through profit or loss. This study aimed to see if the BRI bank disclose financial assets in accordance with SFAS No. 60 adjustment, 2014. The research method is descriptive qualitative. The results showed BRI bank in the disclosure of their financial assets in accordance with SFAS No. 60 adjustment in 2014 but the management did not express because the default has been completed and the loan terms have been renegotiated before the end of the reporting period. Bank BRI to apply IAS 60 and keep abreast of revisions in accordance with the specified standard. So that transparency in the disclosure of financial statements BRI clearer and can build higher trust of our customers and shareholders

Keywords : bank,disclosure, financial instrument
\end{abstract}

\section{PENDAHULUAN}

Perbankan di Indonesia mulai dihadapkan pada tingkat persaingan yang semakin ketat, mereka berlomba-lomba untuk memenangkan persaingan bisnis. Banyaknya perbankan yang ada di Indonesia dewasa ini, menuntut adanya peningkatan kualitas pelayanan jasa sehingga menimbulkan adanya kenyamanan dan kepercayaan masyarakat terhadap perusahaan perbankan tersebut. Pernyataan Standar Akuntansi Keuangan (PSAK) 60 penyesuaian 2014 merupakan standar yang mengatur tentang pengungkapan instrumen keuangan. PSAK 60 adalah hasil revisi dari PSAK 50 (revisi 2006) yang berisi tentang penyajian dan pengungkapan instrument keuangan, yang pada tahun 2010 Ikatan Akuntan Indonesia (IAI) mengambil kebijakan untuk memisahkan isi dari PSAK 50 dimana penyajian instrument keuangan di atur dalam PSAK 50 dan pengungkapan instrumen keuangan di atur dalam PSAK 60, dan mulai berlaku efektif pada 1 januari 2012, dan di revisi pada tahun 2014 maka laporan keuangan perusahaan harus ditata ulang sesuai dengan PSAK yang telah berlaku saat ini.

Pada bank-bank go public menerapkan PSAK 60 dalam laporan keuangan adalah penting, dimana tujuan PSAK 60 adalah mengatur entitas untuk memberikan pengungkapan dalam laporan keuangannya yang memungkinkan pengguna untuk mengevaluasi signifikansi instrumen keuangan bagi posisi dan kinerja keuangan entitas, sifat dan cakupan risiko yang timbul dari instrumen keuangan yang mana entitas terekspos selama periode dan pada akhir periode pelaporan, dan bagaimana entitas mengelola resiko tersebut. 
PT BRI (persero) Tbk sebagai Badan Usaha Milik Negara (BUMN) yang bergerak disektor perbankan dan telah go public, menyadari bahwa keberlangsungan eksistensi perusahaan juga diukur dari performa keuangan, dan peningkatan keuntungan. Berpedoman pada ketentuan yang berlaku, maka perusahaan telah menerapkan ketentuan-ketentuan Standar Akuntansi pada laporan keuangan perusahaan agar menghasilkan laporan keuangan yang berkualitas dan memiliki tingkat keandalan dan relevansi yang tinggi serta dapat meningkatkan kewajaran, keandalan dan transparansi laporan keuangan. Banyaknya Instrumen keuangan yang di miliki mewajibkan BRI untuk menerapkan PSAK 60 dalam laporan keuangannya.

\section{TINJAUAN PUSTAKA}

\subsection{Akuntansi}

Pontoh (2013:1) menyatakan bahwa pada saat ini akuntansi bukanlah sebuah cabang ilmu ekonomi yang baru, akuntansi telah dikenal secara umum dan merupakan sebuah keahlian yang sangat diperlukan.Akuntansi pada dasarnya akan menghasilkan informasi dari sebuah sistem akuntansi yang ada di dalam sebuah entitas atau organisasi bisnis yang disebut dengan informasi akuntansi yang akan dimanfaatkan oleh pengguna seperti masyarakat umum, masyarakat intelektual (termasuk di dalmamnya mahasiswa atau peneliti) dan para pengambil keputusan bisnis dalam organisasi.

Ismail (2010:2) menyatakan bahwa akuntansi dapat diartikan sebagai seni dalam melakukan pencatatan, penggolongan, dan pengikhtisaran, yang mana hasil akhirnya tercipta sebuah informasi seluruh aktivitas keuangan perusahaan.Sedangkan Kieso dan Weygent (2002:2) menyatakan bahwa akuntansi dapat didefinisikan secara tepat dengan menjelaskan tiga karakteristik penting dari akuntansi, yaitu pengidentifikasian, pengukuran, dan pengkomunisian informasi keungan tentang entitas ekonomi kepada pemakai yang berkepentingan.

\subsection{Tinjauan Umum Tentang Bank}

Hasibuan (2011:1) menyatakan bahwa Bank berasal dari kata italia banco yang artinya bangku. Bangku inilah yang dipergunakan oleh bankir untuk melayani kegiatan operasionalnya kepada para nasabah.Istilah bangku secara resmi dan popular menjadi Bank.Supriono (2011:1) menyatakan bahwa Bank termasuk perusahaan industri jasa karena produknya hanya memberikan pelayanan jasa kepada masyarakat. Bank adalah salah satu lembaga keuangan yang beroperasi tidak ubahnya sama seperti perusahaan lainnya, yaitu tujuannya mencari keuntungan.Kasmir (2013:3) memuat pendapat oleh Mohammad Hatta yang mengemukakan bahwa bank adalah sendi kemajuan masyarakat dan sekiranya tidak ada bank maka tidak aka nada kemajuan seperti saat ini. Negara yang tidak mempunyai banyak bank yang baik dan benar adalah negara yang terbelakang, perusahaan saat ini diharuskan memanfaatkan jasa-jasa perbankan dalam kegiatan usahanya jika ingin maju.

\subsection{PSAK 60}

Ikatan Akuntan Indonesia (2012) Pada 17 desember 2010 DSAK-IAI mengeluarkan IFRS 7 sebagai PSAK 60 Instrumen Keuangan: pengungkapan menggantikan persyaratan pengungkapan dalam PSAK 50, meskipun persyaratan penyajian dalam PSAK 50 tidak berubah. Tujuan PSAK 60 adalah mengatur entitas untuk memberikan pengungkapan dalam laporan keuangannya yang memungkinkan pengguna untuk mengevaluasi sgnifikansi instrumen keuangan bagi posisi dan kinerja keuangan entitas tersebut; disamping sifat dan tingkat risiko yang muncul akibat instrumen keuangan tersebut selama periode berjalan dan pada tanggal pelaporan serta bagaimana entitas tersebut mengelola risiko itu. PSAK 60 mensyaratkan untuk mengungkapkan : 


\section{Laporan Posisi Keuangan}

Pembagian aset keuangan dan liabilitas keuangan. Nilai tercatat dari masing-masing kategori, sebagaimana didefinisikan dalam PSAK 55, harus diungkapkan dalam laporan posisi keuangan atau dalam catatan atas laporan keuangan.

Aset keuangan atau liabilitas keuangan pada nilai wajar melalui laba atau rugi. Entitas mengungkapkan metode yang digunakan untuk memenuhi persyaratan, jika entitas meyakini bahwa pengungkapan yang memenuhi persyaratan tidak menyajikan secara jujur perubahan nilai wajar aset keuangan atau liabilitas keuangan yang dapat di atribusikan pada perubahan risiko kredit, alasan-alasan yang menghasilkan kesimpulan tersebut dan faktor-faktor relevan yang dipercayai entitas.

Reklasifikasi. Jika entitas sudah mereklasifikasi suatu aset keuangan sebagai aset yang diukur (i) pada harga perolehan atau biaya amortisasi, bukan pada nilai wajarnya; atau (ii) pada nilai wajar, bukan pada harga perolehan atau biaya amortisasi, PSAK 60 mensyaratkan bahwa entitas itu mengungkapkan jumlah yang direklasifikasikan ke dalam atau dihapus dari masing-masing kategori serta alasan reklasifikasi tersebut.

Saling hapus aset keuangan dan liabilitas keuangan. Jika suatu entitas telah mengalihkan aset keuangan dengan suatu cara yang mengakibatkan sebagian atau seluruh aset keuangan itu tidak memenuhi syarat penghapusan dan pengakuan, PSAK 60 mensyaratkan bahwa entitas itu mengungkapkan sifat aset itu, sifat risiko dan manfaat kepemilikan yang tetap dimiliki entitas itu, nilai tercatat dari aset itu serta liabilitas terkaitnya, nilai tercatat dari aset awal, saldo aset yang tetap diakui oleh entitas itu, serta nilai tercatat dari liabilitas terkaitnya.

Agunan. Jika ada agunan (collateral) tertentu, PSAK 60 mensyaratkan bahwa entitas itu mengungkapkan nilai tercatat dari aset keuangan yang dijamin dalam liabilitas atau liabilitas kontijensi, termasuk saldo yang telah direklasifikasi serta syarat dan ketentuan penjamin tersebut.

Akun penyisihan kerugian kredit. Jika aset keuangan mengalami penurunan nilai karena kerugian kredit dan entitas mencatat penurunan nilai dalam pos terpisah (misalnya pos penyisihan digunakan untuk mencatat penurunan nilai individual atau pos serupa yang digunakan untuk mencatat penurunan nilai kolektif atas aset keuangan) daripada secara langsung mengurangi nilai tercatat aset keuangan, maka entitas mengungkapkan suatu rekonsiliasi perubahan pada akun tersebut selama periode untuk setiap kelompok aset keuangan.

Instrumen keuangan majemuk dengan derivatif melekat. Jika entitas menerbitkan instrumen yang mengandung komponen liabilitas dan ekuitas (lihat PSAK 50:Instrumen Keuangan: Penyajian paragraf 31) dan instrumen tersebut memiliki beberapa derivatif melekat yang nilainya saling tergantung satu sama lain (seperti callable convertibledebt instrument), maka entitas mengungkapkan keberadaan fitur tersebut.

Gagal bayar dan pelanggaran. Untuk utang pinjaman (loans payable) yang diakui pada tanggal pelaporan, PSAK 60 mensyaratkan mengungkapkan (a) Rincian tentang segala gagal bayar selama periode syarat jumlah pokok pinjaman, bunga, dana tebusan, atau penebusan dari utang pinjaman tersebut; (b) Nilai tercatat dari utang pinjaman dalam gagal bayar pada tanggal pelaporan; (c) Apakah gagal bayar telah dipulihkan, atau syarat utang pinjaman dinegosiasikan ulang, sebelum laporan keuangan disahkan pihak berwenang untuk dikeluarkan.

\section{Laporan Laba Rugi dan Penghasilan Komprehensif Lain}

Pos-pos penghasilan, beban, keuntungan dan kerugian. PSAK 60 mensyaratkan pengungkapkan pos-pos penghasilan (income), beban (expense),keuntungan (gain) atau kerugian (loss) berikut ini pada laporan laba-rugi komprehensif atau dalam laporan perubahan ekuitas, atau dalam catatan atas laporan keuangan. 


\section{Pengungkapan Lain}

Kebijakan akuntansi. Sesuai dengan PSAK 1: Penyajian Laporan Keuangan paragraf 117, entitas mengungkapkan dalam ikhtisar kebijakan akuntansi yang signifikan, dasar pengukuran yang digunakan dalam menyusun laporan keuangan dan kebijakan akuntansi lain yang relevan untuk pemahaman suatu laporan keuangan.

Nilai wajar. Kecuali yang diuraikan, untuk setiap kelompok aset keuangan dan liabilitas keuangan, entitas mengungkapkan nilai wajar dari kelompok aset dan liabilitas keuangan tersebut dengan cara yang memungkinkan untuk dibandingkan dengan jumlah tercatatnya.

Pengungkapan Risiko. PSAK 60 mensyaratkan bahwa suatu entitas mengungkapkan informasi yang memungkinkan pengguna laporan keuangannya untuk mengevaluasi sifat dan tingkat risiko yang muncul akibat instrumen keuangan yang dihadapi entitas tersebut pada tanggal pelaporan. Risiko itu biasanya meliputi, namun tidak berbatas pada, risiko kredit, risiko likuiditas, dan risiko pasar.PSAK 60 secara khusus mensyaratkan pengungkapan baik informasi kulitatif maupun informasi kuantitatif.

Pengungkapan kualitatif. Untuk setiap jenis risiko yang timbul dari instrumen keuangan, entitas mengungkapkan (a) eksposur risiko dan bagaimana risiko itu timbul. (b) Tujuan, kebijakan, dan proses pengelolaan risiko dan metode yang digunakan untuk mengukur risiko tersebut. (c) Segala perubahan butir (a) dan (b) dari periode sebelumnya.

Pengungkapan Kuantitatif. Jika data kuantitatif yang diungkapkan pada tanggal pelaporan memperlihatkan risiko yang dihadapi suatu entitas selama periode berjalan, maka entitas tersebut harus mengungkapkan informasi yang representatif. Guna memenuhi persyaratan ini, suatu entitas dapat mengungkapkan jumlah tertinggi, terendah, dan rata-rata resiko yang akan dihadapinya selama periode berjalan. Jenis risiko yang termasuk dalam pengungkapan kuantitatif adalah Risiko kredit, Risiko Likuiditas dan Risiko Pasar.

Tabel 1. Penelitian Terdahulu

\begin{tabular}{|c|c|c|c|c|c|c|c|}
\hline No & $\begin{array}{l}\text { Nama } \\
\text { Peneliti/ } \\
\text { Tahun }\end{array}$ & Judul & $\begin{array}{c}\text { Metode } \\
\text { Penelitian }\end{array}$ & & Hasil Penelitian & Persamaan & Perbedaan \\
\hline 1. & $\begin{array}{l}\text { Agustina } \\
\text { Larasati dan } \\
\text { Supatmi/ } \\
2013\end{array}$ & $\begin{array}{l}\text { Pengungkapan } \\
\text { informasi aset } \\
\text { keuangan dan } \\
\text { impairment- } \\
\text { nya di } \\
\text { perbankan } \\
\text { menurut PSAK } \\
50 \text { dan } 60\end{array}$ & $\begin{array}{l}\text { metode } \\
\text { penelitian } \\
\text { deskriptif } \\
\text { dengan } \\
\text { menggunakan } \\
\text { purposive } \\
\text { sumpling }\end{array}$ & & $\begin{array}{l}\text { aset keuangan } \\
\text { jenis pinjaman } \\
\text { yang diberikan, } \\
\text { dan piutang, } \\
\text { memiliki total aset } \\
\text { keuangan paling } \\
\text { besar, sedangkan } \\
\text { tersedia untuk } \\
\text { dijual memiliki } \\
\text { penurunan nilai } \\
\text { paling besar. } \\
\text { dari tahun 2010- } \\
\text { 2012, semakin } \\
\text { tinggi tingkat } \\
\text { kepatuhan } \\
\text { perbankan untuk } \\
\text { penerapan PSAK } \\
50 \text { dan } 60 . \\
\text { semakin banyak } \\
\text { jumlah perbankan } \\
\text { yang } \\
\text { mengungkapkan } \\
\text { kebijakan } \\
\text { instrumen } \\
\text { keuangan yang } \\
\text { sangat spesifik }\end{array}$ & $\begin{array}{l}\text { variabel } \\
\text { yang sama } \\
\text { yaitu PSAK } \\
60\end{array}$ & $\begin{array}{l}\text { peneliti } \\
\text { sebelumnya } \\
\text { menggunakan } \\
2 \text { variabel } \\
\text { yaitu PSAK } \\
50 \text { dan 60, } \\
\text { objek } \\
\text { berbeda. }\end{array}$ \\
\hline
\end{tabular}




\begin{tabular}{|c|c|c|c|c|c|c|}
\hline No & $\begin{array}{c}\text { Nama } \\
\text { Peneliti/ } \\
\text { Tahun }\end{array}$ & Judul & $\begin{array}{c}\text { Metode } \\
\text { Penelitian }\end{array}$ & Hasil Penelitian & Persamaan & Perbedaan \\
\hline 2. & $\begin{array}{l}\text { Ekaputri } \\
\text { Ciptani } \\
\text { Febriati/2013 }\end{array}$ & $\begin{array}{l}\text { Analisis } \\
\text { penerapan } \\
\text { PSAK 55 atas } \\
\text { cadangan } \\
\text { kerugian } \\
\text { penurunan } \\
\text { nilai }\end{array}$ & $\begin{array}{l}\text { Deskriptif } \\
\text { Kualitatif }\end{array}$ & $\begin{array}{lr}\text { dalam } & \text { penentuan } \\
\text { cadangan penurunan } \\
\text { nilai BRI } & \text { masih } \\
\text { mengacu pada } & \text { PSAK } \\
50 \quad \text { revisi } & 2006) \\
\text { namun } & \text { pada } \\
\text { pengakuan } & \text { dan } \\
\text { pengukuran } & \text { CKPN } \\
\text { BRI } & \text { telah } \\
\text { menerapakan } & \text { PSAK } \\
55 \text { (revisi 2011) dan } \\
\text { sudah sesuai }\end{array}$ & $\begin{array}{l}\text { objek yang } \\
\text { sama yaitu } \\
\text { Bank BRI }\end{array}$ & $\begin{array}{l}\text { Peneliti } \\
\text { sebelumnya } \\
\text { memaparkan } \\
\text { penerapan } \\
\text { PSAK } 55 \\
\text { (revisi 2011) }\end{array}$ \\
\hline 3. & $\begin{array}{l}\text { Lisa Christy } \\
\text { Longgorung/ } \\
\quad 2015\end{array}$ & $\begin{array}{l}\text { Pengungkapan } \\
\text { Instrumen } \\
\text { Keuangan } \\
\text { berdasarkan } \\
\text { PSAK 60 } \\
\text { (studi kasus } \\
\text { pada PT Bank } \\
\text { Rakyat } \\
\text { Indonesia } \\
\text { (persero) Tbk }\end{array}$ & $\begin{array}{l}\text { Deskriptif } \\
\text { Kualitatif }\end{array}$ & $\begin{array}{l}\text { Pengungkapan } \begin{array}{r}\text { aset } \\
\text { keuangan }\end{array} \text { yang } \\
\text { diterapakan PT. Bank } \\
\text { Rakyat Indonesia } \\
\text { (persero) Tbk sudah } \\
\text { sesuai dengan PSAK } \\
60 \text { penyesuaian 2012, } \\
\text { namun dalam } \\
\text { penerapan PSAK 60, } \\
\text { BRI terlalu berfokus } \\
\text { pada pengungkapan } \\
\text { posisi dan kinerja } \\
\text { keuangan, sifat dan } \\
\text { cakupan risiko serta } \\
\text { pengelolaan risiko, } \\
\text { sedangkan dalam poin } \\
\text { gagal bayar dan } \\
\text { pelanggaran, bank BRI } \\
\text { belum } \\
\text { mengungkapkannya. }\end{array}$ & $\begin{array}{c}\text { objek dan } \\
\text { variable } \\
\text { yang sama }\end{array}$ & $\begin{array}{c}\text { Peneliti } \\
\text { sebelumnya } \\
\text { meneliti } \\
\text { PSAK } 60 \\
\text { revisi } 2012\end{array}$ \\
\hline
\end{tabular}

\section{METODE PENELITIAN}

\subsection{Jenis Penelitian}

Jenis penelitian ini adalah penelitian deskriptif untuk memberikan gambaran sistematik dan akurat mengenai fakta, sifat dari hubungan antar fenomena yang diteliti pada suatu perusahaan. Gambaran yang sistematik dan akurat diperoleh dengan mengumpulkan, mengklasifikasi data sehingga akan memberikan hasil yang konkrit pada permasalahan dan kemudian dilaksanakan analisis sehingga dapat ditarik kesimpulan.

\subsection{Sumber Data}

Data yang digunakan dalam penelitian ini berupa data sekunder yaitu dengan menggunakan semua data yang diperoleh dari sumber yang sudah terdokumentasi diperusahaan, seperti sejarah perusahaan, struktur organisasi, dan laporan keuangan konsolidasi dari PT. Bank rakyat Indonesia (Persero) Tbk.

\subsection{Tempat dan Waktu Penelitian}

Penelitian ini mengambil data penelitian di website resmi PT. Bank Rakyat Indonesia (Persero) Tbk. Waktu penelitian dimulai dari bulan Agustus sampai dengan bulan September tahun 2016.

\subsection{Metode Pengumpulan Data}

Sugiyono (2010:410) Metode pengumpulan data dalam penelitian ini adalah studi dokumentasi dan studi perpustakaan yang didapat dari catatan atau dokumen yang ada seperti 
struktur organisasi perusahaan dan laporan keuangan yang disajikan oleh PT. Bank Rakyat Indonesia (Persero) Tbk. pada website resmi bank BRI dan Bursa Efek Indonesia. Penulis menggunakan metode kepustakaan yangdilakukan dengan cara mendapatkan informasi dari teori-teori yang ada dan mempelajari serta mencatat dari buku-buku literatur, jurnal, dan bahan-bahan informasi lainnya yang berhubungan dengan masalah yang diteliti oleh penulis.

\subsection{Metode Analisis Data}

Data dan informasi yang dikumpulkan akan dianalisis dengan menggunakan analisis deskriptif kualitatif yaitu untuk mengumpulkan, menyusun, menganalisis data, memperoleh gambaran sebenarnya bagaimana revisi PSAK 60 penyesuaian 2014 tentang pengakuan informasi aset keuangan pada perusahaan untuk kemudian dibandingkan dengan teori yang ada sehingga mampu memberikan informasi yang lengkap bagi pemecahan masalah yang dihadapi.

\section{HASIL ANALISIS DAN PEMBAHASAN}

\subsection{Hasil Penelitian}

\subsubsection{Sejarah PT. Bank Rakyat Indonesia (PERSRO) Tbk.}

Bank Rakyat Indonesia (BRI) adalah salah satu bank milik pemerintah yang terbesar di Indonesia. Pada awalnya Bank Rakyat Indonesia (BRI) didirikan di Purwokerto, Jawa Tengah oleh Raden Bei AriaWirjaatmadja dan kawan-kawan pada Desember 1895 dengan nama De Poerwokerto Hulp-en Spaarbank derIndlansche Hoofden (Bank Priyayi Poerwokerto). Pada tahun 1898 dengan bantuan pemerintah Hindia Belandadidirikan Volksbanken atau Bank Rakyat, dikota wilayah nusantara atau Hindia Belanda pada waktu itu.Kemudian pada tahun 1934, didirikan Algemene Volkscrediet Bank (AVB) yang berstatus badan hukum Eropa.Pada zaman pendudukan Jepang, berdasarkan UU No. 39 tanggal 3 Oktober 1942 AVB di Pulau Jawa digantinamanya Syamin Ginko (Bank Rakyat). Peraturan pemerintah No. 1-1946 tanggal 22 Februari 1946 tentangaturan "Bank Rakyat Indonesia" menetapkan berdirinya BRI yang merupakan kelanjutan dari Syamin Ginko.Pada masa pendudukan oleh Nederlan Indie Civil Administration bank ini ditutup, namun setelah perjanjian Roem-Royen, BRI kembali menjadi milik Negara 1945.

\subsubsection{Visi dan Misi PT. Bank Rakyat Indonesia (Persero) Tbk.}

Setiap perusahaan mempunyai visi dan misi. Demikian juga dengan PT. Bank Rakyat Indonesia (Persero) Tbk. Visi PT. Bank Rakyat Indonesia (Persero) Tbk. adalah menjadi bank komersial terkemuka yang selalu mengutamakan kepuasan nasabah. Sedangkan misi PT. Bank Rakyat Indonesia (Persero) Tbk. adalah :

1. Melakukan kegiatan perbankan yang terbaik dengan menggunakan Pelayanan Kepada usaha Mikro,Kecil, dan Menengah untuk menunjang peningkatan ekonomi masyarakat ;

2. Memberikan pelayanan prima kepada nasabah melalui jaringan kerja yang tersebar luas dandidukung oleh sumber daya manusia professional dengan melaksanakan Praktek Good CorporateGovernance ;

3. Memberikan keuntungan dan manfaat yang optimal kepada pihak-pihak yang berkepentingan. 


\subsection{Analisis penerapan PSAK 60 penyesuaian 2012 pada Laporan Keuangan PT. Bank Rakyat Indonesia (Persero) Tbk.}

Tabel 1. Perbandingan pengakuan Aset Keuangan berdasarkan PSAK 60 dengan PT BRI (PERSERO) Tbk

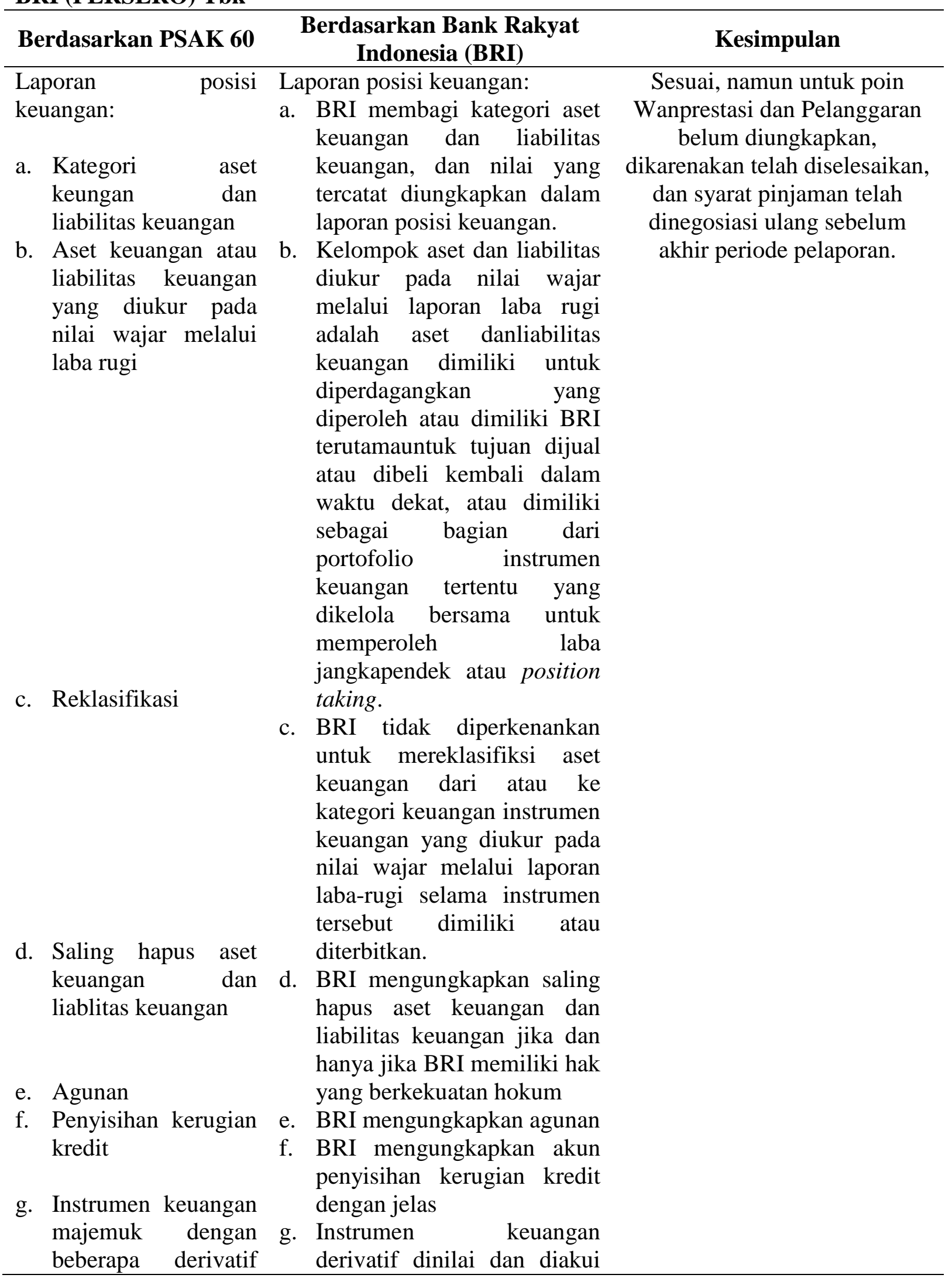




\begin{tabular}{|c|c|c|}
\hline Berdasarkan PSAK 60 & $\begin{array}{c}\text { Berdasarkan Bank Rakyat } \\
\text { Indonesia (BRI) }\end{array}$ & Kesimpulan \\
\hline $\begin{array}{l}\text { melekat } \\
\text { h. Wanprestasi dan } \\
\text { Pelanggaran }\end{array}$ & $\begin{array}{l}\text { dilaporan posisi keuangan } \\
\text { konsolidasian pada nilai } \\
\text { wajar dikurangi cadangan } \\
\text { kerugian penurunan nilai. } \\
\text { h. BRI tidak mengungkapkan } \\
\text { Wanprestasi dan } \\
\text { pelanggaran, karena telah di } \\
\text { selesaikan/dinegosiasikan } \\
\text { kembali sebelum akhir } \\
\text { tanggal pelaporan. }\end{array}$ & \\
\hline $\begin{array}{l}\text { Laporan laba rugi dan } \\
\text { penghasilan } \\
\text { komprehensif lain: } \\
\text { a. Pos penghasilan, } \\
\text { beban, keuntungan, } \\
\text { atau kerugian. }\end{array}$ & $\begin{array}{l}\text { Laporan laba rugi dan } \\
\text { penghasilan komprehensif lain : } \\
\text { a. BRI mengungkapkan } \\
\text { pendapatan, dalam laporan } \\
\text { laba-rugi komprehensif dan } \\
\text { beban, keuntungan, atau } \\
\text { kerugian dalam laporan } \\
\text { perubahan ekuitas. }\end{array}$ & Sesuai \\
\hline $\begin{array}{l}\text { Pengungkapan lain: } \\
\text { a. Kebijakan } \\
\text { Akuntansi } \\
\text { b. Nilai Wajar }\end{array}$ & $\begin{array}{l}\text { Pengungkapan lain: } \\
\text { a. BRI mengungkapkan } \\
\text { Kebijakan Akuntansi yang } \\
\text { digunakan. } \\
\text { b. BRI mengukur nilai wajar } \\
\text { dari suatu instrumen dengan } \\
\text { menggunakan hargakuotasi } \\
\text { di pasar aktif untuk } \\
\text { instrumen terkait. }\end{array}$ & Sesuai \\
\hline $\begin{array}{l}\text { Sifat cakupan risiko } \\
\text { instrumen keungan: } \\
\text { a. Risiko kredit } \\
\text { b. Risiko Likuiditas }\end{array}$ & $\begin{array}{l}\text { Sifat cakupan risiko instrumen } \\
\text { keungan: } \\
\text { a. BRI mengungkapkan risiko } \\
\text { kredit yang dihadapi serta } \\
\text { kemungkinan kerugian yang } \\
\text { diakibatkan oleh tidak } \\
\text { terbayarnya pinjaman yang } \\
\text { diberikan dan kontrak } \\
\text { keuangan lainnya, baik } \\
\text { secara tingkat individual } \\
\text { maupun portofolio kredit } \\
\text { secara keseluruhan dapat } \\
\text { dikelola seminimal } \\
\text { mungkin. }\end{array}$ & Sesuai \\
\hline c. Risiko Pasar & \begin{tabular}{lr} 
b. & \multicolumn{2}{c}{ BRI mengungkapkan risiko } \\
likuiditas yang dihadapi \\
dengan & menerapkan \\
kebijakan yang bertujuan \\
untuk r memastikan
\end{tabular} & \\
\hline
\end{tabular}




\begin{tabular}{|c|c|c|}
\hline Berdasarkan PSAK 60 & $\begin{array}{c}\text { Berdasarkan Bank Rakyat } \\
\text { Indonesia (BRI) }\end{array}$ & Kesimpulan \\
\hline & $\begin{array}{l}\text { kecukupan dana harian } \\
\text { dalam memenuhi kewajiban } \\
\text { pada kondisi normal maupun } \\
\text { kondisi krisis secara tepat } \\
\text { waktu dari berbagai sumber } \\
\text { dana yang tersedia. termasuk } \\
\text { memastikan ketersediaan } \\
\text { aset likuid berkualitas tinggi. } \\
\text { c. BRI mengungkapkan sistem } \\
\text { aplikasi yang di gunakan } \\
\text { treasury dan risiko pasar } \\
\text { (GUAVA) rontuk } \\
\text { menghindari risiko pasar } \\
\text { timbul karena pergerakan } \\
\text { faktor pasar yang meliputi } \\
\text { suku bunga dan nilai tukar } \\
\text { yang berlawanan dengan } \\
\text { posisi yang dimiliki BRI, } \\
\text { baik posisi yang ada di } \\
\text { laporan posisi keuangan } \\
\text { maupun rakening } \\
\text { administratif. }\end{array}$ & \\
\hline
\end{tabular}

(sumber: olahan 2016)

\subsection{Pembahasan}

Pernyataan Standar Akuntansi Keuangan (PSAK) 60 penyesuaian 2014 merupakan standar yang mengatur tentang pengungkapan instrumen keuangan. Dengan tujuan mengatur entitas untuk memberikan pengungkapan dalam laporan keuangannya yang memungkinkan pengguna untuk mengevaluasi signifikansi instrumen keuangan bagi posisi dan kinerja keuangan entitas, sifat dan cakupan risiko yang timbul dari instrumen keuangan yang mana entitas terekspos selama periode dan pada akhir periode pelaporan, dan bagaimana entitas mengelola resiko tersebut.Pada pengakuan awal PT. Bank Rakyat Indonesia (persero) Tbk telah memisahan kategori aset keuangan dan liabiitas keuangan, dimana aset keuangan dan liabilitas keuangan diukur pada nilai wajar melalui laporan laba-rugi. BRI juga mengungkapkan pendapatan dalam laporan laba-rugi komprehensif dan beban, keuntungan, atau kerugian dalam laporan perubahan ekuitas, BRI juga mengungkapkan pengukuran nilai wajar dari setiap kelas aset keuangan dan liabilitas keuangan, dan BRI mengungkapkan dan menjelaskan risiko kredit, risiko likuiditas dan risiko pasar, serta pengelolaan resiko dengan sangat jelas, tetapi BRI belum mengungkapan gagal bayar dan pelanggaran karena telah di selesakian dan di negosiasi ulang sebelum akhir tgl pelaporan.

\section{KESIMPULAN DAN SARAN}

\subsection{Kesimpulan}

Kesimpulan yang diambil dari penelitian ini adalah: Pengungkapan aset keuangan yang diterapakan PT. Bank Rakyat Indonesia (persero) Tbk sudah sesuai dengan revisi PSAK 60 penyesuaian 2014, namun dalam penerapan PSAK 60, BRI terlalu berfokus pada pengungkapan posisi dan kinerja keuangan, sifat dan cakupan risiko serta pengelolaan risiko, sedangkan dalam poin gagal bayar dan pelanggaran, bank BRI belum mengungkapkannya. 


\subsection{Saran}

Pengungkapan Instrumen keuangan, bank BRI sudah menerapkan dan mengikuti revisi PSAK 60 penyesuaian 2014 dalam laporan keuangan namun, ada poin pengungkapan yang belum di ungkapkan oleh BRI. Penulis menyarankan, agar pimpinan bank BRI untuk menerapkan keseluruhan dari PSAK 60 dan terus mengikuti perkembangan perubahan standar akuntansi keuangan dan menerapkan pada laporan keuangan perusahaan sesuai standar yang berlaku. Sehingga transparansi pada pengungkapan laporan keuangan BRI lebih jelas dan dapat membangun kepercayaan yang lebih tinggi dari nasabah dan para pemegang saham PT. bank Rakyat Indonesia (persero) Tbk.

\section{DAFTAR PUSTAKA}

Andric.,M., Mijic, K \& Jaksic., D. 2011. Financial Reporting And Characteristics of Impairment of Assets in The Republic of Serbia According To IAS/IFRS And National Regulation. Economic Annuals, Vol LVI, No. 189.

Febriati Ekaputri Ciptani 2013. Analisa Penerapan PSAK 55 atas Cadangan Kerugian Penurunan Nilai. Universitas Sam Ratulangi Manado. Jurnal EMBA ISSN: 2303-1174 Vol.1 No.3 Juni 2013. http://ejournal.unsrat.ac.id/index.php/emba/article/view/1648. Diakses 22 September 2014. Hal 207-217.

Hasibuan, Malayu. 2011 Dasar-Dasar Perbankan.Cetakan kesembilan. Bumi Aksara. Jakarta.

Ikatan Akuntan Indonesia 2012 Standar Akuntansi Keuangan. Cetakan pertama. Dewan Standar Akuntansi Keuangan Ikatan Akuntansi Indonesia, Jakarta.

Ismail. 2010. Manajemen Perbankan dari Teori Menuju Aplkasi. Penerbit Kencana. Jakarta. Kasmir. 2013 Dasar-dasar Perbankan. Edisi revisi. RajaGrafindo Persada, Jakarta.

Kieso, Donald dan Weygent. 2002. Akuntansi Intermediate.Edisi 10 jilid 2. Penerbit Erlangga. Jakarta.

Larasati Agustina dan Supatmi 2013.Pengungkapan Informasi aset keuangan dan Impairment-nya Di Perbankan menurut PSAK 50 dan 60. Publikasi Ilmiah UMS.Fakultas Ekonomika dan Bisnis, UKSW salatiga. ISBN: 978-602-70429-1-9 http://publikasiilmiah.ums.ac.id/handle/123456789/4650. Diakses pada 20 September 2014. Hal 296-309.

Longgorung Lisa Christy 2015. Pengungkapan Informasi Aset Keuangan Menurut PSAK 60 pada PT Bank Rakyat Indonesia (persero) Tbk. Universitas Sam Ratulangi Manado. Jurnal EMBA ISSN: 2303-1174 Vol.3 No.1 Maret 2015.

Pontoh, Winston. 2013 Akuntansi Konsep dan Aplikasi. Halaman Moeka, Jakarta.

Supriyono, Maryanto. 2011. Buku pintar Perbankan. Edisi Pertama. ANDI, Yogyakarta.

Sugiyono. 2010. Metode Penelitian Bisnis (Pendekatan Kuantitatif, Kualitatif, dan R\&D). Alfabeta, Bandung. 